\title{
Invited review: The effects of processing parameters on the flavor of whey protein ingredients
}

\author{
B. G. Carter and M. A. Drake ${ }^{1}$ \\ Department of Food, Bioprocessing and Nutrition Sciences, Southeast Dairy Foods Research Center, North Carolina State University, \\ Raleigh 27695
}

\begin{abstract}
Whey protein ingredients are used in a wide variety of products and are added primarily for nutritional benefits or functionality, not for flavor. However, the processes used to further refine fluid whey produce and encourage development of off-flavors that carry through to the final product. From the milk source to spray drying, each step contributes to the oxidation of lipids, which negatively affects flavor. An understanding of the sources of these flavor constituents and volatile compounds, as well as how they are formed during processing and handling, are important to eliminate or reduce undesirable flavors and for understanding how to best incorporate these ingredients into high-quality finished products.
\end{abstract}

Key words: whey, flavor, processing

\section{INTRODUCTION}

Liquid whey is a co-product of cheese manufacturing. Once considered a waste product, the demand for dried whey ingredients has steadily increased over the past decade to over 180 million metric tonnes produced per year (Smithers, 2015). Demand for whey protein ingredients owes to their unique nutritional and functional properties (Foegeding et al., 2002; Tunick, 2008).

Whey composition is dependent on cheesemaking. Whey can be distinguished as either sweet or acid whey, with a typical $\mathrm{pH}$ range of 6 to 6.3 and 4.3 to 4.6, respectively (Morr and Ha, 1993). Traditionally, sweet whey is produced by the addition of rennet to cheese milk, and acid whey by acidification by either fermentation of lactose into lactic acid by starter culture or direct addition of acid. Sweet whey has a higher fat content, which results from the starting milkfat of the cheese milk. Acid whey is higher in ash and lactic acid (Kosikowski and Mistry, 1997).

Received February 10, 2018.

Accepted April 18, 2018.

${ }^{1}$ Corresponding author: maryanne_drake@ncsu.edu
Protein is currently the most valuable component of whey. The major proteins that contribute to the protein fraction of the whey stream are $\beta-\mathrm{LG}, \alpha-\mathrm{LA}$, serum albumin, immunoglobulins, and protease peptone (Jayaprakasha and Brueckner, 1999). About $80 \%$ of the total whey protein is composed of $\beta-\mathrm{LG}$ and $\alpha-\mathrm{LA}$ (Schmidt et al., 1984). Membrane technologies permit an increase in the protein content while reducing the carbohydrate, mineral, and water contents. Generally, the higher percentage of protein content, the higher the nutritional value of the product (Onwulata, 2008).

Whey proteins are added to a final product for added nutritional benefit or functionality, not for flavor. Whey proteins ideally have bland or no flavor; however, numerous published studies have demonstrated that whey protein and dried whey ingredients have flavor (Carunchia Whetstine et al., 2003; Mahajan et al., 2004; Carunchia Whetstine et al., 2005; Wright et al., 2006, 2009). Further, these flavors can carry over to finished products, which can limit applications of different dried dairy ingredients (Drake, 2006; Wright et al., 2009; Evans et al., 2010; Oltman et al., 2015).

The main tool used to characterize flavor of foods and ingredients is trained panel profiling or descriptive analysis (Drake, 2007). Trained panel profiling or descriptive sensory analysis can be a powerful tool for describing and differentiation of product flavors and identifying and quantifying specific flavors in products (Meilgaard et al., 1999; Drake, 2007). Panelists are highly trained $(>100 \mathrm{~h})$ and calibrated on reference materials that allow accurate and consistent results. Volatile compound analysis by GC provides information on specific volatile compounds that may contribute to flavor. Gas chromatography separates individual volatile compounds based on interaction with coating on a column (Kataoka et al., 2000). Gas chromatography-olfactometry splits the stream of separated volatile compounds from GC through an instrumental detector and a sniffer port, where a human sniffer identifies which volatiles compounds are odor active (Van Ruth and O'Connor 2001; d'Acampora Zellner et al., 2008). These tools allow researchers to investigate flavor and 
flavor sources that are key tools in understanding how specific processing steps affect flavor. Both sensory analysis and GC-olfactometry methods have been reviewed previously (Van Ruth and O'Connor, 2001; Drake, 2007; Schiano et al., 2017).

Volatile compounds are responsible for flavors in dried whey ingredients. An understanding of the sources of these flavor constituents and volatile compounds, as well as how they are formed during processing and handling, are important to eliminate or reduce undesirable flavors and for understanding how to best incorporate these ingredients into high-quality finished products. This review will focus on the flavor of whey and whey protein concentrates and how whey ingredient flavor is affected by processing conditions.

\section{WHEY PROCESSING}

The advancement of membrane processing capabilities has led to a wide range of dried whey products with varying protein content. Membrane processing and whey protein ingredient manufacturing have been reviewed by Daufin et al. (2001) and Morr and Ha (1993). After whey has been separated from the cheese curd, the whey is clarified, separated, and pasteurized. In a colored cheese process, the whey is bleached to remove residual colorant that remains in the whey stream from the cheese milk (McDonough et al., 1968; Smith et al., 2014). Bleaching can be accomplished enzymatically or by addition of a chemical oxidizing agent (Kang et al., 2010). Filtration processes are then applied to concentrate the protein, followed by spray drying.

Different whey protein products (34-90\% protein of the TS) exist for specific product applications (Morr and Foegeding, 1990). The most common techniques used for the membrane filtration of dairy products are microfiltration (MF), UF, nanofiltration, and reverse osmosis (RO). These different filtration technologies have key differences in terms of particle size, molecular weights, and the components that they separate (Daufin et al., 2001; Bylund, 2003; Pouliot, 2008). During filtration, 2 streams are produced: retentate and permeate. Retentate is the concentrate that is retained by the membrane, permeate is the filtrate that passes through the membrane (Bylund, 2003).

Microfiltration can be used to fractionate proteins, remove bacteria, further separate whey fat, and fractionate native milk fat globules (Fauquant et al., 2005; Michalski et al., 2006; Marcelo and Rizvi, 2008; Onwulata, 2008; Zulewska et al., 2009). Ultrafiltration separates macromolecules such as proteins and suspended particles. Ultrafiltration is commonly applied to separate protein from NPN, lactose, water, and minerals. Reverse osmosis uses a semipermeable membrane that allows water to pass through, but not salts, sugars, and small molecular compounds. The osmotic pressure on one side of the membrane increases greatly and if pressure is applied to that side, pure water can be achieved (Rosenberg, 1995). Nanofiltration fills the gap in pore size between UF and RO. The fact that this membrane process removes water and minerals makes this process very useful in demineralizing whey, milk, and the UF permeate of both milk and whey (Anonymous, 2000).

\section{Whey Ingredients}

Sweet whey powder is a dried product that contains all of the same components of whey in similar ratios to liquid sweet whey from the cheese vat. It typically is not fractionated by membrane filtration and usually contains $70 \%$ lactose, $1.5 \%$ fat, $12 \%$ protein, $4 \%$ moisture, and $8.5 \%$ other solids (US Dairy Export Council, 2004). Whey protein concentrates are obtained by removing nonprotein components to achieve higher protein percentages. Whey protein concentrates range from 34 to $90 \%$ (US Dairy Export Council. 2004). Ultrafiltration is typically used to achieve these higher protein percentages by reducing lactose, mineral, NPN, and water content.

Whey protein isolate (WPI) contains $>90 \%$ protein on a dry weight basis. Microfiltration is used to remove excess lipid from sweet whey. Whey protein isolate is made from the permeate of the MF process; WPI can also be produced through ion exchange chromatography (Anonymous, 2003; Huffman 1996). Serum proteins (sometimes referred to as native whey protein) are separated by direct filtration of skim milk. Both ceramic and spiral-wound membranes can be used to separate casein and serum proteins with differing efficiencies (Zulewska et al., 2009; Beckman et al., 2010; Hurt et al., 2010; Adams and Barbano, 2013). Serum protein concentrates are created from the skim milk permeate from the MF. Serum protein concentrates and isolates are further concentrated through UF. Serum proteins have low levels of lipid, as they have already gone through an MF step to isolate the serum proteins from casein micelles.

\section{Flavors in Whey}

Flavors in liquid whey have been divided into dairy and nondairy flavors (Carunchia Whetstine et al., 2003; Drake, 2006). Dairy flavors are those found in fresh milk and whey and include sweet aromatic and cooked or milky flavors (Carunchia Whetstine et al., 2003). Nondairy flavors are atypical of dairy products and include cardboard, animal or wet dog, cucumber, and many others (Carunchia Whetstine et al., 2003). 
Fresh sweet liquid whey ideally has sweet aromatic and buttery flavors (Carunchia Whetstine et al., 2003). Karagül-Yüceer et al. (2003) identified short-chain fatty acids, aldehydes, ketones, lactones, sulfur compounds, phenols, indoles, pyrazines, furans, and pyrroles compounds and noted over 34 aroma-active compounds that contributed to the flavor of liquid Cheddar whey.

Mozzarella fluid whey is different in flavor profile from Cheddar fluid whey (Gallardo Escamilla et al., 2005a; Liaw et al., 2011). The differences in starter cultures and cheesemaking procedures between Mozzarella and Cheddar are the source of these flavor differences. Smith et al. (2016a) demonstrated that whey from different cheesemakings produced distinct flavors in WPI. Wright et al. (2009) found that WPC 80 (whey protein concentrate with $80 \%$ protein) produced from mozzarella cheese whey was generally lower in flavor volatiles than WPC 80 from Cheddar whey. The differences in $\mathrm{pH}$, starter culture, and cheesemaking had a major effect on the fluid whey flavor and dried whey protein flavor, as well as the functionality. Whey from different cheese sources can also have differences in protein-toprotein interactions, $\mathrm{pH}$, ionic strength, and sulfur and covalent linkages, which could be a driving factor for the difference in flavor (Nishanthi et al., 2017).

The main sources of off-flavors in both liquid and dried whey are volatile lipid oxidation compounds, even though whey has relatively small amounts of lipid (Morr and Ha, 1991; Swaisgood, 1996). Proteolytic enzymes present in the cheese milk, including chymosin added to form the curd, may also degrade AA, leading to offflavor formation (Holmes et al., 1977; Garoutte et al., 1985; Campbell and Drake, 2013a). Off-flavors develop due to the extensive amount of processing that must be done to concentrate whey proteins. Evidence exists that proteins bind flavors during processing, contributing to the flavor of the finished product (Stevenson et al., 1996). Park et al. (2014b) demonstrated that certain volatiles were bound to whey protein during spray drying.

When the variable of the cheesemaking is removed, the flavor of the serum proteins can be more directly documented. Evans et al. (2009, 2010) noted key flavor differences between spray-dried serum proteins and whey proteins. Serum protein concentrate (SPC) with $34 \%$ protein had lower flavor intensities when compared with WPC 34. At $10 \%$ solids, SPC 34 was relatively clear whereas WPC 34 was cloudy, most likely due to the higher fat content. Similar differences were demonstrated in WPC 80 and SPC 80 (Evans et al., 2010). Spray-dried WPC 34 and WPC 80 had higher concentrations of volatile lipid oxidation compounds than SPC 34 and SPC 80, consistent with lower intensities of cardboard flavor. Protein beverages made with SPC 80 had consumer liking scores that were higher or at parity in aroma, appearance, and mouthfeel as beverages made with WPC 80.

\section{SOURCES OF OFF-FLAVOR DEVELOPMENT IN WHEY}

Cardboard flavor is a ubiquitous flavor in whey proteins (Carunchia Whetstine et al., 2005; Russell et al., 2006). This flavor is defined as the flavor of cardboard and the reference for panel training can be prepared by soaking pieces of cardboard in water (Carunchia Whetstine et al., 2005; Russell et al., 2006). Cardboard flavor has been linked to volatile lipid oxidation products (Wright et al., 2009; Whitson et al., 2010, 2011). Other flavors in whey proteins, including cabbage, potato, and fatty flavors, have also been reported and linked to lipid oxidation (Wright et al., 2006, 2009; Whitson et al., 2011).

\section{Lipid Oxidation}

Lipid oxidation causes the fatty acids esterified on triacylglycerols and phospholipids to decompose and form volatile compounds. In whey products, the hydroperoxides formed are mainly derivatives of oleic, linoleic, and linolenic acids. These are among the most common UFA to undergo lipid oxidation (Frankel, 1998). The oleic, linoleic, and linolenic acid content $(\mu \mathrm{g} / \mathrm{g}$ of liquid whey) in fresh liquid whey are 0.23 , 3.33 , and 0.86 , respectively (Tomaino et al., 2004). The hydroperoxides formed are unstable and break down to form secondary lipid oxidation products; these secondary lipid oxidation products include acids, alcohols, aldehydes, carbonyls, and ketones (Frankel, 1998).

These lipid oxidation compounds are responsible for off-flavors in liquid and dried whey products (Evans et al., 2009, 2010; Whitson et al., 2010, 2011; Campbell et al., 2011a,b; Liaw et al., 2011). The cheesemaking process produces many different compounds. In fresh fluid whey, short- and long-chain free fatty acids are present from the starter culture. Aldehydes, a major oxidation product of UFA, have been identified in fresh fluid whey (Carunchia Whetstine et al., 2003; Drake et al., 2003; Karagül-Yüceer et al., 2003; Gallardo-Escamilla et al., 2005a; Campbell et al., 2011a; Fox et al., 2013). Lipid oxidation compounds were also observed in freshly manufactured dried proteins (Carunchia Whetstine et al., 2005; Whitson et al., 2011). Because lipid oxidation is present in fresh manufactured whey (Tomaino et al., 2004; Carunchia Whetstine et al., 2005; Whitson et al., 2011), subsequent processing steps must minimize further oxidation to prevent further off-flavor formation. 


\section{Maillard Reactions}

The Maillard reaction is one of the predominant chemical interactions of food components during processing and storage (Sikorski et al., 2008). The Maillard reaction is also called nonenzymatic browning because the end-products are brown-colored pigments. Apart from brown color, the Maillard reaction also produces flavors. The reaction requires a reducing sugar and an amine-containing compound such as a protein, peptide, or AA. In dairy products, lactose is generally the primary reducing sugar that participates in the Maillard reaction (Sikorski et al., 2008). Lipid oxidation products, such as methyl ketones, aldehydes, and free fatty acids, can also react with Maillard reaction products to further deteriorate food quality (Newton et al., 2012). Maillard reactions are common in dried whey ingredients, such as sweet whey powder, due to the high lactose content (Mahajan et al., 2004). Their role in the flavor of fresh dried whey ingredients is diminished as protein content increases (Carunchia Whetstine et al., 2005).

For the Maillard reaction to be stopped, the moisture content must fall below 3\%, a value that is not reached in dried dairy ingredients (Sienkiewicz and Riedel, 1990). Maillard reaction and lipid oxidation products contribute to the flavors of dried whey ingredients (Mahajan et al., 2004; Carunchia Whetstine et al., 2005). In whey products with higher levels of lactose, such as sweet whey powder, Maillard compounds play a large role in their flavor. In whey products with lower levels of lactose, such as WPC or WPI, Maillard reaction compounds have fewer contributions to flavor and flavor is dominated by lipid oxidation products, barring extended storage at $>30^{\circ} \mathrm{C}$ (Carunchia Whetstine et al., 2005; Tunick et al., 2016). Storage time and temperature have an effect on rate of Maillard reaction compounds and the resulting flavor. Sithole et al. (2006) investigated storage of SWP at different temperatures (35, 45, 50, and $55^{\circ} \mathrm{C}$ ) to understand the rate of deterioration under accelerated conditions. Over 19 mo of storage, major differences in color and physicochemical parameters occurred. Increased storage temperature increased the rate of deterioration of sweet whey powder.

Javidipour and Qian (2008) investigated storage of commercial WPC 80 and tracked volatile compound changes of powders stored at 35,40 , and $45^{\circ} \mathrm{C}$ for 15 wk. Volatile lipid oxidation compounds increased with storage temperature and time. In 2 studies with SWP, WPC 34, and WPC 80, browning increased with storage, with SWP and WPC 34 exhibiting the most browning over storage, consistent with higher lactose content (Sithole et al., 2006; Tunick et al., 2016). Maillard reactions occurred faster with increasing lactose or storage temperatures but also occurred at refrigeration temperatures (Tunick et al., 2016).

\section{PROCESSING STEPS THAT ENCOURAGE LIPID OXIDATION}

There are many considerations to control the consistency of whey flavor and the development off-flavors. Many cheese manufacturing plants produce several styles of cheese, and when a plant processes whey these different styles are typically combined and may be stored before being processed (Tunick, 2008). This process presents a problem, as different cheese types (starter cultures and cheesemaking procedures) produce different flavors in fluid whey (Carunchia Whetstine et al., 2003; Gallardo-Escamilla et al., 2005a,b; Drake et al., 2009b; Smith et al., 2016a). Table 1 summarizes different processes that affect the flavor of whey.

\section{Milk}

Croissant et al. (2007) investigated pasture and TMR feed effects on the flavor of milk. The 2 milks were distinct by descriptive analysis as well as by volatile compound analysis. Milks from pasture-fed cows were characterized by grassy flavor compared with TMR milk, which was characterized by malty and sweet aromatic flavors. International milk, cheese, and dairy ingredients differ in flavor from domestic (US) dairy products. International dairy products have been characterized by grassy, cowy, and mothball flavors (Drake et al., 2003; 2009a). Most international dairy products are from cows grazed on pasture, whereas domestic dairy products are typically from TMR-fed cows. The feed of the dairy cow contributes to the flavor of fluid milk and the dried dairy ingredients produced from that milk.

The level of milk fat in the cheese milk also affects the resulting whey flavor. Campbell et al. (2011a) investigated the flavor stability of fresh and stored whole and skim milk and Cheddar cheese whey produced from skim and whole milk. Skim milk and skim milk cheese whey were higher in free fatty acids (hexanoic, octanoic, decanoic, dodecanoic, tetradecanoic, hexadecanoic, octadecanoic, oleic, linoleic, and linolenic) compared with whole milk and whey produced from whole milk. The higher relative amounts of oleic, linoleic, and linolenic are a possible cause for increased lipid oxidation products in skim milk. Cream separation of milk adds another processing step that has high shear and often incorporates air. After separation, the low level of lipid that remains in the skim milk is higher in phospholipid (Gallier et al., 2010). Skim milk as well as the whey produced from skim milk were higher in lipid oxidation 
products, and the higher phospholipid content is a possible source of off-flavors (Morr and Ha, 1993).

\section{Starter Culture}

Mineral content, lactose, and protein composition as well as flavor of fluid whey can all be affected by starter culture (Bordenave-Juchereau et al., 2005; Gallardo-Escamilla et al., 2005a,b). Starter cultures are a source of flavor variability and lipid oxidation in liquid whey (Carunchia Whetstine et al., 2003; Tomaino et al., 2004). Liaw et al. (2010) demonstrated that lipid oxidation products were present in fresh fluid whey, indicating that previous processes initiated the oxidation of lipids. Both Liaw et al. (2011) and Campbell et al. (2011a) demonstrated that fluid whey produced from Cheddar and Mozzarella cheese starter cultures were distinct in flavor and lipid oxidation profile. Campbell et al. (2011a) compared these traditional cheese whey to whey produced by rennet addition without starter culture to better understand the effect of starter culture addition. Whey made without starter culture were lower in sweet aromatic, buttery, and sour aromatic flavors, but were also lower in lipid oxidation products. Cheddar whey (mesophilic culture) were higher in diacetyl, decanal, heptanal, nonanal, and acetic acid compared with Mozzarella whey (thermophilic culture). Both fluid whey from Cheddar and Mozzarella starter cultures had higher levels of lipid oxidation products compared with whey without starter culture (Campbell et al., 2011a). Starter culture had a greater effect on the flavor of whey than the differences in the specific cheesemaking between Cheddar and Mozzarella (Campbell et al., 2011a). Different mesophilic strains, such as Lactococcus lactis ssp. lactis, were also distinct in lipid oxidation profiles. The format of the starter culture media, frozen or freeze-dried, did not have an effect on flavor (Campbell et al., 2011a).

A similar subsequent experiment was performed with WPC and the findings were similar to those found in

Table 1. Processing conditions that affect whey and whey protein flavor

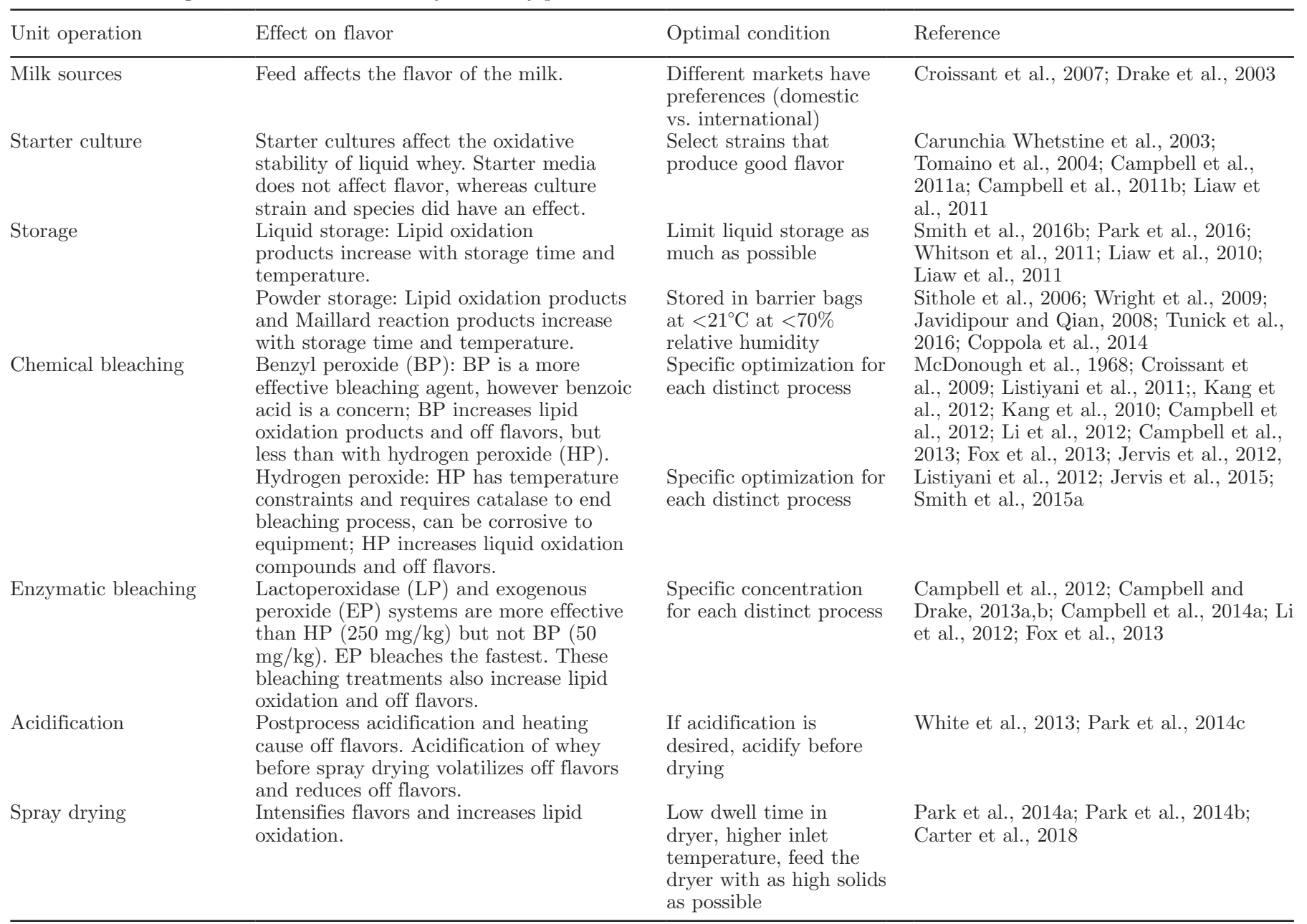


fluid whey (Campbell et al., 2011b). The WPC made with cultured whey had higher concentrations of lipid oxidation products compared with WPC from whey without starter culture (Campbell et al., 2011b). Lipid oxidation starts with the milk and continues through the cheesemaking and through storage of the liquid whey (Campbell et al., 2011b). The addition of starter culture increases lipid oxidation products, and consideration for which culture to use can have an effect on fluid whey and WPC flavor. Ultimately, the flavor of the milk and the subsequent fluid whey directly influence the flavor of the resulting dried ingredient.

\section{Liquid Storage}

Often, cheese is produced in one plant and the whey is transported and processed in another facility. Liquid storage is detrimental to the flavor of dried whey ingredients. Storage of pasteurized fat separated or unseparated whey $4^{\circ} \mathrm{C}$ resulted in increased lipid oxidation (Tomaino et al., 2004; Campbell et al., 2011a; Liaw et al., 2011; Whitson et al., 2011).

Storage negatively affects all cheese whey. Liaw et al. (2010) compared fresh and stored liquid Mozzarella and Cheddar whey, and mozzarella whey demonstrated lower flavor intensities and lipid oxidation compounds initially compared with Cheddar whey. However, both liquid whey increased in cardboard and oxidized flavors with storage at $4^{\circ} \mathrm{C}$, concurrent with increases in lipid oxidation compounds. Smith et al. (2016b) showed that $4^{\circ} \mathrm{C}$ storage of liquid pasteurized whey from Cheddar, Mozzarella, cottage cheese, acid, and rennet whey increased in lipid oxidation flavors with 24 and $48 \mathrm{~h}$ of $4^{\circ} \mathrm{C}$ storage time. Greek yogurt whey was the most stable of the acid whey, whereas rennet casein was the most stable of the sweet whey (Smith et al., 2016b). Special consideration should be made in plant design as well as process design to limit storage as much as possible to have the best-tasting whey products.

Whitson et al. (2011) investigated the influence of storage at $4^{\circ} \mathrm{C}$ on the flavor of liquid WPC 80 and WPI retentates. Liquid whey proteins were stored for $6,12,24$, or $48 \mathrm{~h}$ and then subsequently dried, and the flavor of the rehydrated powder was evaluated. Storage of liquid WPC or WPI retentate increased lipid oxidation products and sulfur degradation products in the spray-dried protein powder (Whitson et al., 2011). Storage time as short as $2 \mathrm{~h}$ had an effect and increased lipid oxidation products, although little effect on sensory perception was noted until $6 \mathrm{~h}$ of storage (Whitson et al., 2011). To minimize flavor effects, liquid protein retentates should be held for less than $12 \mathrm{~h}$ before spray drying (Whitson et al., 2011). If storage is necessary, bleached whey stored better as liquid whey, and un- bleached whey stored better as liquid WPC 80 (Park et al., 2016).

One way to reduce the effects of storage is the addition of antioxidants, such as ascorbic acid and whey protein hydrolysate (Liaw et al., 2010). Liaw et al. (2011) added these antioxidants to liquid whey from Mozzarella and Cheddar cheese manufacturing to determine effects on the oxidative stability of liquid whey and spray-dried WPC. Lipid oxidation compounds were more prevalent in fresh and stored liquid Cheddar whey than in liquid Mozzarella whey. Removal of fat from liquid whey decreased but did not eliminate lipid oxidation in liquid whey. Cardboard flavor and aldehyde content were significantly lower with the use of ascorbic acid in liquid whey and WPC compared with the control. However, during storage of WPC, the antioxidant activity of ascorbic acid decreased with time, and lipid oxidation off-flavors developed with prolonged storage due to reduced ascorbic acid activity. Whey protein hydrolysate also lowered intensities of cardboard flavor and aldehyde content, but it contributed potato, brothy, and malty flavors. Although whey protein hydrolysate performed well as an antioxidant, the off-flavors it contributed to the final product were undesirable.

\section{Chemical Bleaching}

Orange Cheddar cheese in the United States is iconic and something that many of consumers expect (Drake et al., 2009b). Annatto (norbixin), a plant-derived carotenoid, is added to Cheddar cheese milk to produce the desired orange color. Approximately $10 \%$ of the added colorant partitions into the whey and, once concentrated, imparts color to dried protein ingredients (Kang et al., 2010; Smith et al., 2014). Chemical bleaching agents and enzymatic bleaching are commonly used to break down color pigments. Hydrogen peroxide (HP) and benzyl peroxide (BP) are the 2 chemical agents legally allowed for whey bleaching in the United States (Kang et al., 2010). Some concerns exist with bleaching by-products in other countries. Benzoic acid (BA) is formed when BP is oxidized in fluid whey; BA is a concern for exports to countries with restricting regulations, such as China (USDA, 2010).

Chemical bleaching and enzymatic agents are nonspecific oxidative processes that oxidize double bonds of the carotenoid pigment, reducing overall color (Kang et al., 2010). The oxidative process also reduces levels of other carotenoids, such as $\alpha$-tocopherol, retinol, $\beta$-carotene, and $\alpha$-carotene, and vitamins, such as ascorbic acid (Stout et al., 2017). Several studies have documented that the decolorization of whey using chemical bleaching agents also increases lipid oxida- 
tion (McDonough et al., 1968; Croissant et al., 2009; Listiyani et al., 2011; Campbell et al., 2012; Kang et al., 2012; Smith et al., 2015b). Mortenson et al. (2008) reported that bleaching had no effect on the flavor of reconstituted WPC and WPI. Mortenson et al. (2008) reported volatile compound differences, but no differences detected by sensory analysis. Products were produced at several facilities, varying from industrial scale to pilot plant, and direct comparisons of bleached and unbleached whey produced at 1 facility were not conducted. As such, the effect of bleaching on the flavor of WPC and WPI was confounded. Many other studies have established relationships between bleaching lipid oxidation and off flavors in whey protein.

Croissant et al. (2009) produced liquid whey under controlled conditions and evaluated different bleaching agents (BP, HP) on the same lot of fluid whey to directly compare the effect of the bleaching agents on the flavor of the fluid whey and WPC. Bleaching of fluid whey with HP resulted in higher intensities of cardboard and fatty flavors and their corresponding volatile lipid oxidation products in WPC 70 compared with unbleached controls and BP. In WPC 34 manufacture, bleaching of fluid whey with BP (50 or 100 $\mathrm{mg} / \mathrm{kg}$ ) resulted in lower intensities of cardboard flavor and volatile lipid oxidation products than bleaching with HP (500 mg/kg; Listiyani et al., 2011). Jervis et al. (2012) reported similar results when WPC 80 was produced and Smith et al. (2015b) reported similar results with WPI. Both specific bleaching agents as well as bleach concentration affected norbixin destruction and whey flavor (Croissant et al., 2009; Listiyani et al., 2011; Campbell et al., 2012; Kang et al., 2012); however, the bleaching process increased lipid oxidation products and off-flavor regardless of bleach type used.

$\mathrm{Li}$ et al. (2012) investigated bleaching efficacy of whey with HP $(250 \mathrm{mg} / \mathrm{kg})$ and how bleaching efficacy was effected by different processing steps. Whey was produced and sampled without starter culture as well as before and after pasteurization, fat separation, after storage at $4^{\circ} \mathrm{C}$, and freezing at $-20^{\circ} \mathrm{C}$ for $10 \mathrm{~d}$. Bleaching efficacy of whey was not affected by starter culture, whey pasteurization, or fat separation. Storage, whether cold or frozen, decreased bleaching efficiency and norbixin reduction.

The negative flavor effects of bleaching on whey remained consistent when the cheese make procedure was removed. SPC 80 was made from the milk serum stream and bleached with HP or BP and similar results to those when bleaching Cheddar whey to process WPC 80 were documented. BP was more effective as a bleaching agent and resulted in lower levels of lipid oxidation products compared with HP (Campbell et al., 2013).
Li et al. (2012) investigated the effect of whey solids at time of bleaching on norbixin destruction. Using WPC 34 and WPC 80 retentates diluted to 7 or $9 \%$ solids, as well as rehydrated WPC 34 and WPC 80 powders at 9 and $12 \%$ solids, there was no difference in bleaching efficacy between the different solids ( $\mathrm{Li}$ et al., 2012). Rehydrated WPC 34 powder had greater norbixin destruction than liquid WPC 34 to a level equivalent to immediate bleaching of liquid whey, whereas liquid WPC 80 had a higher norbixin destruction than rehydrated WPC 80 (Li et al., 2012). Higher protein percentages in whey concentrates had higher bleaching efficacies, likely due to the contribution of lactoperoxidase concentrated with the protein (Li et al., 2012; Fox et al., 2013). Using the same bleach concentration (HP $250 \mathrm{mg} / \mathrm{kg}$ ) at $50^{\circ} \mathrm{C}$, liquid WPC 80 retentate had more norbixin destruction than liquid WPC 34 retentate. These results demonstrated that solids did not affect bleaching efficacy, but the composition of the solids had an effect. Although higher TS did not affect bleaching efficacy, bleaching at higher solids did cause higher concentrations of lipid oxidation compounds.

Benzoyl peroxide bleaching was not affected by temperature, but HP was a more effective bleaching agent at 50 than $5^{\circ} \mathrm{C}$ (Li et. al., 2012; Fox et al., 2013). Bleaching at higher temperatures with $\mathrm{BP}$ or HP resulted in higher lipid oxidation products compared bleaching at lower temperature (Listiyani et al., 2012; Fox et al., 2013). Numerous studies have demonstrated that BP was a more effective bleaching agent than HP in liquid whey (Jervis et al., 2012; Listiyani et al., 2012; Campbell et al., 2013; Fox et al., 2013; Jervis et al., 2015). However, once whey is concentrated by UF, HP was a more effective bleaching agent than BP, also likely due to lactoperoxidase concentration (Listiyani et al., 2012; Fox et al., 2013).

Benzoyl peroxide can be used as a powder or a liquid dispersion. Smith et al. (2015a) evaluated bleaching of liquid whey and powdered WPC 80 with a traditional BP powder and a liquid dispersion (Smith et al., 2015a). Liquid BP bleached faster than the powdered $\mathrm{BP}$ at lower concentrations, which lead to lower benzoic acid residues. Bleaching with liquid $\mathrm{BP}$ at lower temperatures resulted in higher cardboard flavors and lipid oxidation products in WPC 80 than WPC 80 from whey bleached at $50^{\circ} \mathrm{C}$ with powdered BP (Smith et al., 2015a). Liquid-dispersed BP achieved more bleaching with a lower concentration of $\mathrm{BP}$ resulting in reduced $\mathrm{BA}$ residues in WPC 80 (Smith et al., 2015a). The WPC 80 had less BA than WPC 34, and more BA was recovered from the resulting permeate. The BA passes through the UF membrane, and therefore a product that has gone through more stages of filtration will be further reduced in BA. Benzoic acid levels were reduced 
with UF and diafiltration (Listiyani et al., 2011). Concentrating sweet whey with RO before bleaching with $\mathrm{BP}$ reduced $\mathrm{BA}$ residues when compared with whey that was bleached without being concentrated (Jervis et al., 2015). The best strategies to reduce BA levels with $\mathrm{BP}$ bleaching were use of liquid dispersed BP, UF, or by concentrating the whey before bleaching.

\section{Enzymatic Bleaching}

The lactoperoxidase (LP) system is another method for bleaching whey. It activates via the natural LP enzyme present in the whey as well as low concentrations of added HP and native thiocyanate. All 3 components must be present in sufficient amounts to activate the system (Seifu et al., 2005). Lactoperoxidase activity in raw milk, pasteurized milk, fat-separated pasteurized liquid whey, and fluid retentate ( $80 \%$ protein) did not decrease during refrigerated storage or freezing for 0 , 24, 48, or $72 \mathrm{~h}$ (Campbell et al., 2014); however, there were differences in concentrations of LP between these different matrices. A small amount of HP (10-40 mg of $\mathrm{HP} / \mathrm{kg}$ ) was added to activate the system, as not enough HP is naturally present $(30 \mathrm{~g} / \mathrm{L})$ (Campbell et al., 2012). The activated system creates hypothiocyanate, which is a powerful oxidizing agent for bleaching and also acts as an antimicrobial (Kang et al., 2010; Campbell and Drake, 2013b). The bleaching of liquid whey using the LP system was more effective than HP chemical bleaching and required significantly less HP (20 vs. $250 \mathrm{mg}$ of $\mathrm{H}_{2} \mathrm{O}_{2} / \mathrm{kg}$ ). The LP activity of whey varied from 0.001 to 11.1 and LP activity was not affected by pasteurization (Campbell and Drake, 2014). The activity of LP in a concentrated whey stream increased as $\mathrm{pH}$ (up to 6.50) and temperature (up to $50-60^{\circ} \mathrm{C}$ ) increased (Campbell and Drake, 2013b).

Enzymatic bleaching of liquid whey using the LP system for WPC 80 increased intensities of cardboard and cabbage flavors and relative abundances of volatile lipid oxidation compounds compared with an unbleached control WPC 80 (Campbell et al., 2012). Native LP was concentrated with other proteins by UF. When WPC 80 retentate was bleached in place of fluid whey, faster bleaching occurred (Campbell and Drake, 2013b). Higher protein content increased bleaching efficiency with LP and traditional HP (Li et al., 2012; Campbell and Drake, 2013b; Fox et al., 2013). Lactoperoxidase makes up approximately $0.5 \%$ of total whey protein content; therefore, once concentrated with other whey proteins, LP concentration increases bleaching efficiency in more concentrated whey protein retentates.

Commercial exogenous peroxidases are also available to enhance fluid whey bleaching (Kang et al., 2010;
Campbell and Drake, 2013b; Szweda et al., 2013). The mechanisms for the enzyme are not completely understood, but the enzyme is isolated from a mushroom, Marasmius scorodonius (Zorn et al., 2010). This enzyme also requires a small amount of HP to activate the system. Exogenous peroxidase (EP) enzyme did not produce dried dairy ingredients with better flavor, but bleaching endpoints were reached faster, making it a valuable option to increase production speed (Campbell et al., 2014). Campbell and Drake (2013b) investigated the effectiveness of chemical and enzymatic bleaching agents at $4^{\circ} \mathrm{C}$. Hydrogen peroxide was ineffective at cold temperatures but was slightly more effective in WPC 80 retentate, which was consistent with previous research (Listiyani et al., 2012; Campbell and Drake, 2013b; Fox et al., 2013). The EP enzymatic bleaching was faster than chemical bleaching at $4^{\circ} \mathrm{C}$ in fluid whey $(\mathrm{EP}=1 \mathrm{~h}, \mathrm{LP}=12 \mathrm{~h}, \mathrm{HP}=12 \mathrm{~h})$. In WPC 80 retentate, the addition of EP did not increase bleaching speed at $4^{\circ} \mathrm{C}$ (Campbell and Drake, 2013b). Bleaching at lower temperatures also resulted in lower levels of lipid oxidation products (Listiyani et al., 2012; Campbell and Drake, 2013b; Fox et al., 2013).

Bleaching of sweet whey was compared with 4 different bleaching treatments, HP $\left(250 \mathrm{mg} / \mathrm{kg}, 50^{\circ} \mathrm{C}, 60\right.$ $\min ), \mathrm{BP}\left(50 \mathrm{mg} / \mathrm{kg}, 50^{\circ} \mathrm{C}, 60 \mathrm{~min}\right), \mathrm{LP}(20 \mathrm{mg} / \mathrm{kg}$ of $\mathrm{HP}, 50^{\circ} \mathrm{C}, 60 \mathrm{~min}$ ), and EP (MaxiBright, DSM Food Specialties, Delft, the Netherlands; 2 dairy bleaching units $\left./ \mathrm{mL}, 50^{\circ} \mathrm{C}, 30 \mathrm{~min}\right)$ at normal solids $(6.7 \%)$ and at $14 \%$ solids concentrated by RO (Jervis et al., 2015). Bleaching at a higher solids increased the total amount of volatiles formed, and for HP, LP, and EP bleached sweet whey, higher levels of lipid oxidation products were measured in the resulting sweet whey powder products, consistent with previous work (Jervis et al., 2015).

Increased EP activity did not correlate to an increase in norbixin destruction in WPC 34 and WPC 80 (Campbell and Drake, 2014). Retentates bleached enzymatically at higher temperatures bleached faster but had higher intensities of off-flavors, which was also documented with chemical bleaching agents ( $\mathrm{Li}$ et al., 2012; Listiyani et al., 2012; Fox et al., 2013). The effectiveness of the native LP system relies on the amount of LP naturally present in the milk, and with the addition of EP, more consistent bleaching results were achieved (Campbell et al., 2014).

\section{Alternatives to Chemical and Enzymatic Bleaching}

The removal of the annatto colorant in Cheddar whey through bleaching increases off-flavor intensities and corresponding lipid oxidation products. To produce 
whey proteins from colored whey with reduced amounts of off-flavors and lipid oxidation, careful control to optimize efficiency of bleaching while minimizing detrimental effects is needed. Optimization must be applied for each product and for each company-specific process. As many flavor issues and problems with chemical and enzymatic bleaching systems are possible, there is a need for alternatives that might be less detrimental to flavor.

Ultraviolet radiation, acid-activated bentonite, and ozone were investigated for potential uses as bleaching agents in liquid whey for WPC80 manufacture (Kang et al., 2012). Bleaching with bentonite resulted in WPC80 with lower concentrations of volatile lipid oxidation products and higher bleaching efficacy compared with WPC 80 from HP-bleached whey. Bleaching with UV radiation and ozone resulted in distinct mushroom/ burnt and animal flavors and higher concentrations of volatile lipid oxidation products compared with the bentonite and control treatments (Kang et al., 2012). Activated carbon has also been evaluated as an alternative bleaching agent. Activated carbon was more effective at removing norbixin and reducing $b$ values (yellow color values) than bleaching with HP in fluid whey (Zhang et al., 2015). Whey treated by activated carbon was also lower in lipid oxidation products compared with bleached samples.

Microfiltration can also be used to remove fat and is typically used to defat whey for WPI manufacture (Daufin et al., 2001). Norbixin has been shown to associate with the milk fat globule membrane; therefore, it holds some promise when using MF to physically remove colorant as opposed to destroying it (Zhu and Damodaran, 2012). When used in the production of WPC 80 for norbixin removal, MF was as effective as HP but not as effective as the LP system. Both HP and LP bleached WPC 80 had higher cardboard and cabbage flavors compared with unbleached WPC 80 and a WPC 80 produced by microfiltration (Qiu et al., 2015).

\section{Acidification}

Acidification of WPC 80 retentate $(\mathrm{pH} 3.5)$ before spray drying decreased off-flavors and concentrations of lipid oxidation products (Park et al., 2014b). To more clearly define the effect of acidification on flavor, deuterated hexanal was added to the liquid WPC 80 retentate before spray drying and was measured in the liquid as well as the resulting WPC 80 powder. Lower amounts of deuterated hexanal were recovered in the powder, suggesting that the change in $\mathrm{pH}$ changed the way flavor compounds bind to whey proteins and made them more volatile, thus reducing flavor in spray dried powder (Park et al., 2014b).

\section{Spray Drying and Storage of Dried Powders}

Spray drying is the most frequent method used in the dairy industry to produce dried products. Spray drying involves atomizing liquid feed into a spray of droplets that swirl with hot air in a drying chamber evaporating the water (Masters, 1991). Spray drying is the most convenient and economical means of dehydrating to stabilize protein ingredients for a longer shelf-life (Schuck, 2002). Sithole et al. (2006) suggested that new flavors are not developed from the drying of powder, but that existing flavors are intensified. Carter et al. (2018) investigated the actual effect of spray drying on whey protein flavor by comparing the flavor of liquid retentate to the spray dried powder. Both WPC 80 and WPI had higher overall flavor as well as higher lipid oxidation products in the powder form compared with the liquid retentate. Spray drying increased lipid oxidation products and concurrent off-flavors. Spray drying WPC 80 at increased temperatures $\left(200-220^{\circ} \mathrm{C}\right)$ and higher solids (18-25\%) produced lower off-flavor intensities (Park et al., 2014a). Increased temperature and feed solids resulted in higher particle size and lower surface free fat. The lower surface free fat was attributed to lower levels of off-flavors due to lower surface area of lipid and oxygen surface (Park and Drake, 2014). Lower off-flavors in powders can be achieved with a higher spray drying temperature and a higher percent feed solids.

Wright et al. (2009) examined stored WPC and WPI powders over $18 \mathrm{mo}$ of storage at $21^{\circ} \mathrm{C}$. Sensory and volatile compound analysis indicated that the flavor of WPC 80 and WPI deteriorated due to specific lipid oxidation-derived flavors and that volatile lipid oxidation products increased with storage. Further processing steps, such as agglomeration and instantizing, increased lipid oxidation compared with nonagglomerated or noninstantized products (Wright et al., 2009). Off-flavors were detected in steam and lecithin-agglomerated whey protein at 4 to $6 \mathrm{mo}$ as opposed to the nonagglomerated whey proteins, which showed the same defects within 6 to $10 \mathrm{mo}$ of dried storage (Wright et al., 2009). Stored instantized WPC 80 had higher off-flavor formation during storage at 35,40 , and $45^{\circ} \mathrm{C}$ than regular WPC 80 (Javidipour and Qian, 2008). The WPC 34 and WPC 80 powders increased in hexanal and other lipid oxidation products over storage at ambient temperatures (Tunick et al., 2016). Powders stored at higher temperatures $\left(35^{\circ} \mathrm{C}\right)$ had a shorter shelf life due to yellowing and clumping (Tunick et al., 2016). Storage at higher temperature increased the concentration of lipid oxidation products as well as Maillard reactions (Tunick et al., 2016; Coppola 
et al., 2014). Volatile compounds increased with storage temperature as well as time. The extended storage of powders should be limited, and extra drying steps, such as instantization and agglomeration, decrease shelf stability. Finally, dairy powders including whey proteins can absorb taints from packaging materials or the storage environment, so care must be taken with both packaging and storage environment (Andrewes et al., 2010).

\section{CONCLUSIONS}

Whey protein flavor is complex. To produce the highest-quality dried ingredient, it is important to consider how the process from beginning to end affects the flavor and therefore acceptability of the product. Through careful control of processing parameters, protein ingredients with minimal color and flavor can be made for endless product applications.

\section{ACKNOWLEDGMENTS}

Funding was provided in part by the National Dairy Council (Rosemont, IL). The use of trade names does not imply endorsement or lack of endorsement of those not mentioned.

\section{REFERENCES}

Adams, M. C., and D. M. Barbano. 2013. Serum protein removal from skim milk with a 3 -stage, $3 \mathrm{x}$ ceramic isoflux membrane process at $50{ }^{\circ}$ C. J. Dairy Sci. 96:2020-2034.

Andrewes, P., J. G. Bendall, G. Davey, and R. Shingleton. 2010. A musty flavor defect in calcium caseinate due to chemical tainting by 2.4.6-tribromophenol and 2,4,6-tribromoanisole. Int. Dairy J. 20:423-428.

Anonymous. 2000. Membrane Filtration and Related Molecular Separation Technologies. APV Systems, Kilkeborg, Denmark.

Anonymous. 2003. Dairy Processing Handbook. Tetra Pak Processing Systems AB, Lund, Sweden.

Beckman, S. L., J. Zeluwska, M. Newbold, and D. M. Barbano. 2010. Production efficiency of micellar casein concentrate using polymeric spiral-wound microfiltration membranes. J. Dairy Sci. 93:4506-4517.

Bordenave-Juchereau, S., B. Almeida, J. Piot, and F. Sannier. 2005. Effect of protein concentration, $\mathrm{pH}$, lactose content and pasteurization on thermal gelation of acid caprine whey protein concentrates. J. Dairy Res. 72:34-38.

Bylund, G. 2003 Dairy Processing Handbook. Tetra Pak Processing Systems AB, Lund, Sweden.

Campbell, R. E., S. Adams, M. A. Drake, and D. M. Barbano. 2013 Effect of bleaching permeate from microfiltered skim milk on $80 \%$ serum protein concentrate. J. Dairy Sci. 96:1387-1400.

Campbell, R. E., and M. A. Drake. 2013a. The impact of native and non-native enzymes on the flavor of dried dairy ingredients. J. Dairy Sci. 96:4773-4783.

Campbell, R. E., and M. A. Drake. 2013b. Cold enzymatic bleaching of fluid whey. J. Dairy Sci. 96:7404-7413.

Campbell, R. E., and M. A. Drake. 2014. Enzymatic bleaching in commercial colored cheddar whey retentate. Int. Dairy J. 38:148-153.
Campbell, R. E., P. D. Gerard, and M. A. Drake. 2014. Characterizing endogenous and exogenous peroxidase activity for bleaching of fluid whey and retentate. J. Dairy Sci. 97:1225-1232.

Campbell, R. E., E. J. Kang, E. Bastian, and M. A. Drake. 2012. The use of lactoperoxidase for the bleaching of fluid whey. J. Dairy Sci. 95:2882-2890.

Campbell, R. E., R. E. Miracle, and M. A. Drake. 2011b. The effect of starter culture and annatto on the flavor and functionality of whey protein concentrate. J. Dairy Sci. 94:1185-1193.

Campbell, R. E., R. E. Miracle, P. Gerard, and M. A. Drake. 2011a. Effects of starter culture and storage on the flavor of liquid whey. J. Food Sci. 76:S354-S361.

Carter, B., H. Patel, D. M. Barbano, and M. A. Drake. 2018. The impact of spray drying on the difference in flavor and functional properties of liquid and dried whey proteins, milk proteins, and micellar casein concentrates. J. Dairy Sci. 101:3900-3909.

Carunchia Whetstine, M. E., A. E. Croissant, and M. A. Drake. 2005. Characterization of dried whey protein concentrate and isolate flavor. J. Dairy Sci. 88:3826-3839.

Carunchia Whetstine, M. E., J. D. Parker, M. A. Drake, and D. K. Larick. 2003. Determining flavor and flavor variability in commercially produced liquid Cheddar whey. J. Dairy Sci. 86:439-448.

Coppola, L. E., M. S. Molitor, S. A. Rankin, and J. A. Lucey. 2014 Comparison of milk-derived whey protein concentrates containing various levels of casein. Int. J. Dairy Technol. 67:467-473.

Croissant, A. E., E. J. Kang, R. E. Campbell, E. Bastian, and M. A. Drake. 2009. The effect of bleaching agent on the flavor of liquid whey and whey protein concentrate. J. Dairy Sci. 92:5917-5927.

Croissant, A. E., S. P. Washburn, L. L. Dean, and M. A. Drake. 2007. Chemical properties and consumer perception of fluid milk from conventional and pasture-based production systems. J. Dairy Sci. 90:4942-4953

d'Acampora Zellner, B., P. Dugo, G. Dugo, and L. Mondello. 2008. Gas chromatography olfactometry in food flavour analysis. J. Chromatogr. A 1186:123-143.

Daufin, G., J. P. Escudier, H. Carrere, S. Berot, L. Fillaudeau, and M. Decloux. 2001. Recent and emerging application of membrane processes in the food and dairy industry. Food Bioprod. Process. 79:89-102.

Drake, M. A. 2006. Flavor and flavor carry-through of whey proteins in beverages. Page 292-300 in The Wonders of Whey... Catch the Power. Proceedings of the 4th International Whey Conference. American Dairy Products Institute, Elmhurst, IL.

Drake, M. A. 2007. Invited review: Sensory analysis of dairy foods. J. Dairy Sci. 90:4925-4937.

Drake, M. A., S. Clark, M. Costello, and F. Bodyfelt. 2009b. The Sensory Evaluation of Dairy Products. 2nd ed. Springer Science New York, NY.

Drake, M. A., Y. Karagul-Yuceer, K. R. Cadeallader, G. V. Civille, and P. S. Tong. 2003. Determination of the sensory attributes of dried milk powders and dairy ingredients. J. Sens. Stud. 18:199-216.

Drake, M. A., J. Wright, M. Whitson, and M. Lloyd. 2009a. Impact of dairy ingredients on the flavor profiles of foods. Pages 442-466 in Dairy-Derived Ingredients: Food and Nutraceutical Uses. CRC Press, Boca Raton, FL.

Evans, J., J. Zulewska, M. Newbold, M. A. Drake, and D. M. Barbano. 2009. Comparison of composition, sensory, and volatile components of thirty-four percent whey protein and milk serum protein concentrates. J. Dairy Sci. 92:4773-4791.

Evans, J., J. Zulewska, M. Newbold, M. A. Drake, and D. M. Barbano. 2010. Comparison of composition and sensory properties of $80 \%$ whey protein and milk serum protein concentrates. J. Dairy Sci. 93:1824-1843

Fauquant, C., V. Briard, N. Leconte, and M. C. Michalski. 2005. Differently sized native milk fat globules separated by microfiltration: fatty acid composition of the milk fat globule membrane and triglyceride core. Eur. J. Lipid Sci. Technol. 107:80-86.

Foegeding, E. A., J. P. Davis, D. Doucet, and M. K. McGuffey. 2002. Advances in modifying and understanding whey protein functionality. Trends Food Sci. Technol. 13:151-159. 
Fox, A. J., T. J. Smith, P. D. Gerard, and M. A. Drake. 2013. The influence of bleaching agent and temperature on bleaching efficacy and volatile components of fluid whey and whey retentate. J. Food Sci. 78:C1535-1542.

Frankel, E. N. 1998. Oxidation in multiphase systems. Pages 259-297 in Lipid Oxidation. The Oily Press, Dundee, Scotland.

Gallardo-Escamilla, F. J., A. L. Kelly, and C. M. Delahunty. 2005a. Influence of starter culture on flavor and headspace volatile profiles of fermented whey and whey produced from fermented milk. J. Dairy Sci. 88:3745-3753.

Gallardo-Escamilla, F. J., A. L. Kelly, and C. M. Delahunty. 2005b. Sensory characteristics and related volatile flavor compound profiles of different types of whey. J. Dairy Sci. 88:2689-2699.

Gallier, S., D. Gragson, C. Cabral, R. Jiménez-Flores, and D. W. Everett. 2010. Composition and fatty acid distribution of bovine milk phospholipids from processed milk products. J. Agric. Food Chem. 58:10503-10511.

Garoutte, C. A., C. H. Amundson, and C. A. Ernstrom. 1985. Residual milk coagulants in whey - Their inactivation and effects on ultrafiltration flux and nitrogen yields. J. Dairy Sci. 68:817-821.

Holmes, D. G., J. W. Duersch, and C. A. Ernstrom. 1977. Distribution of milk clotting enzymes between curd and whey and their survival during Cheddar cheese making. J. Dairy Sci. 60:862-869.

Huffman, L. M. 1996. Processing whey protein for use as a food ingredient. Food Technol. 2:49-52.

Hurt, E., J. Zulewska, M. Newbold, and D. M. Barbano. 2010. Micellar casein concentrate production with a $3 \mathrm{x}, 3$-stage, uniform transmembrane pressure ceramic membrane process at $50^{\circ} \mathrm{C}$. J. Dairy Sci. 93:5588-5600.

Javidipour, J., and M. Qian. 2008. Identification of volatile compound changes in whey protein concentrate using head space solid phase microextraction-gas chromatography-olfactometry-mass-spectrometry. Dairy Sci. Tech. 88:95-104.

Jayaprakasha, H. M., and H. Brueckner. 1999. Whey protein concentrate: a potential functional ingredient for food industry. J. Food Sci. Technol. 36:189-204.

Jervis, M. G., T. J. Smth, and M. A. Drake. 2015. The influence of solids concentration and bleaching agent on bleaching efficacy and flavor of sweet whey powder. J. Dairy Sci. 98:2294-2302.

Jervis, S., R. E. Campbell, K. L. Wojciechowski, E. A. Foegeding, M. A. Drake, and D. M. Barbano. 2012. Effect of bleaching whey on sensory and functional properties of $80 \%$ whey protein concentrate. J. Dairy Sci. 95:2848-2862.

Kang, E. J., R. E. Campbell, E. Bastian, and M. A. Drake. 2010. Invited review: Annatto usage and bleaching in dairy foods. J. Dairy Sci. 93:3891-3901

Kang, E. J., T. J. Smith, and M. A. Drake. 2012. Alternative bleaching methods for Cheddar cheese whey. J. Food Sci. 77:C818-823.

Karagül-Yüceer, Y., M. A. Drake, and K. R. Cadwallader. 2003 Aroma-active components of liquid cheddar whey. J. Food Sci. $68: 1215-1219$.

Kataoka, H., H. L. Lord, and J. Pawliszyn. 2000. Applications of solid-phase microextraction in food analysis. J. Chromatogr. A 880:35-62.

Kosikowski, F. V., and V. V. Mistry. 1997. Whey and whey foods. Pages 422-453 in Cheese and Fermented Milk Foods: Volume I: Origins and Principles. 3rd ed. F. V. Kosikowski LLC, Wesport, CT.

Li, X. E., R. E. Campbell, A. J. Fox, P. D. Gerard, and M. A. Drake. 2012. Influence of storage, heat treatment, and solids composition on the bleaching of whey with hydrogen peroxide. J. Food Sci. 77:C798-C804

Liaw, I. W., H. Eshpari, P. S. Tong, and M. A. Drake. 2010. The impact of antioxidant addition on flavor of Cheddar and Mozzarella whey and Cheddar whey protein concentrate. J. Food Sci. 75:C559-C569

Liaw, I. W., R. E. Miracle, S. M. Jervis, M. A. D. Listiyani, and M. A. Drake. 2011. Comparison of the flavor chemistry and flavor stability of Mozzarella and Cheddar wheys. J. Food Sci. 76:C1188-1194.
Listiyani, M. A. D., R. E. Campbell, R. E. Miracle, D. M. Barbano, and M. A. Drake. 2012. Effect of temperature and bleaching agent on bleaching of liquid cheddar whey. J. Dairy Sci. 95:36-49.

Listiyani, M. A. D., R. E. Campbell, R. E. Miracle, L. O. Dean, and M. A. Drake. 2011. Influence of bleaching on flavor of $34 \%$ whey protein concentrate and residual benzoic acid concentration in dried whey proteins. J. Dairy Sci. 94:4347-4359.

Mahajan, S. S., L. Goddick, and M. C. Qian. 2004. Aroma compounds in sweet whey powder. J. Dairy Sci. 87:4057-4063.

Marcelo, P. A., and S. H. Rizvi. 2008. Physicochemical properties of liquid virgin whey protein isolate. Int. Dairy J. 18:236-246.

Masters, K. 1991. Spray Drying Handbook. Longman Scientific \& Technical, Harlow, Essex, United Kingdom.

McDonough, F. E., R. E. Hargrove, and R. P. Tittsler. 1968. Decolorization of annatto in Cheddar cheese whey. J. Dairy Sci. 51:471472.

Meilgaard, M., G. V. Civille, and B. T. Carr. 1999. Descriptive analysis techniques. Pages 161-172 in Sensory Evaluation Techniques. 3rd ed. M. Meilgaard, G. V. Civille, and B. T. Carr, ed. CRC Press, Boca Raton, FL.

Michalski, M. C., N. Leconte, V. Briard-Bion, J. Fauquant, J. L. Maubois, and H. Goudédranche. 2006. Microfiltration of raw whole milk to select fractions with different fat globule size distributions: Process optimization and analysis. J. Dairy Sci. 89:3778-3790.

Morr, C. V., and E. A. Foegeding. 1990. Composition and functionality of commercial whey and milk protein concentrates and isolates: a status report. Food Technol. 44:100.

Morr, C. V., and E. Y. W. Ha. 1991. Off-flavors of whey protein concentrates: A literature review. Int. Dairy J. 1:1-11.

Morr, C. V., and E. Y. W. Ha. 1993. Whey protein concentrates and isolates: Processing and functional properties. Crit. Rev. Food Sci. Nutr. 33:431-476.

Mortenson, M. A., Z. M. Vickers, and G. A. Reineccius. 2008. Flavor of whey protein concentrates and isolates. Int. Dairy J. 18:649-657.

Newton, A. E., A. J. Fairbanks, M. Golding, P. Andrewes, and J. A. Gerrard. 2012. The role of the Maillard reaction in the formation of flavor compounds in dairy products - Not only a deleterious reaction but also a rich source of flavor compounds. Food Funct. 3:1231-1241.

Nishanthi, M., T. Vasiljevic, and J. Chandrapala. 2017. Properties of whey proteins obtained from different whey streams. Int. Dairy J. 66:76-83.

Oltman, A. E., K. Lopetcharat, E. Bastian, and M. A. Drake. 2015. Identifying key attributes for protein beverages. J. Food Sci. 80:S1383-S1390.

Onwulata, C. I. 2008. Milk whey processes: Current and future trends. Pages 369-391 in Whey Processing, Functionality, and Health Benefits. C. I. Onwulata, and P. J. Huth, ed. Wiley-Blackwell, Ames, IA.

Park, C. W., E. Bastian, B. E. Farkas, and M. A. Drake. 2014a. The effect of feed solids concentration and inlet temperature on the flavor of spray dried whey protein concentrate. J. Food Sci. 79:C19C24.

Park, C. W., E. Bastian, B. E. Farkas, and M. A. Drake. 2014b. The effect of acidification of liquid whey protein concentrate on the flavor of spray dried powder. J. Dairy Sci. 97:4043-4051.

Park, C. W., and M. A. Drake. 2014. The distribution of fat in dried dairy particles determines flavor release and flavor stability. J. Food Sci. 79:R452-R459.

Park, C. W., M. Parker, and M. A. Drake. 2016. Short communication: The effect of liquid storage on the flavor of whey protein concentrate. J. Dairy Sci. 99:4303-4308.

Pouliot, T. 2008. Membrane processes in dairy technology-From a simple idea to worldwide panacea. Int. Dairy J. 18:735-740.

Qiu, Y., T. J. Smith, E. A. Foegeding, and M. A. Drake. 2015. The effect of microfiltration on color, flavor and functionality of $80 \%$ whey protein concentrate. J. Dairy Sci. 98:5862-5873.

Rosenberg, M. 1995. Current and future applications for membrane processes in the dairy industry. Trends Food Sci. Technol. 6:12-15. 
Russell, T. A., M. A. Drake, and P. D. Gerard. 2006. Sensory properties of whey and soy proteins. J. Food Sci. 71:S447-S455.

Schiano, A. N., W. S. Harwood, and M. A. Drake. 2017. A 100-year review: Sensory analysis of milk. J. Dairy Sci. 100:9966-9986.

Schmidt, R. H., V. S. Packard, and H. A. Morris. 1984. Effect of processing on whey protein functionality. J. Dairy Sci. 67:2723-2733.

Schuck, P. 2002. Spray drying of dairy products: State of the art. Lait $82: 375-382$.

Seifu, E., E. M. Buys, and E. F. Donkin. 2005. Significance of the lactoperoxidase system in the dairy industry and its potential applications: A review. Trends Food Sci. Technol. 16:137-154.

Sienkiewicz, T., and C. L. Riedel. 1990. Whey and Whey Utilization. Possibilities for Utilization in Agriculture and Foodstuffs Production. Verlag Th. Mann, Gelsenkirchen-Buer, Germany.

Sikorski, Z. E., J. Pokorny, and S. Damodaran. 2008. Physical and chemical interactions of components in food systems. Pages 860 867 in Fennema's Food Chemistry. 4th ed. S. Damodaran, K. L. Parkin, and O. R. Fennema, ed. CRC Press, Boca Raton, FL.

Sithole, R., M. R. McDaniel, and L. M. Goddik. 2006. Physicochemical, microbiological, aroma, and flavor profile of selected commercial sweet whey powders. J. Food Sci. 71:157-163.

Smith, S., T. J. Smith, and M. A. Drake. 2016b. Short communication: Flavor and flavor stability of cheese, rennet, and acid wheys. J. Dairy Sci. 99:3434-3444.

Smith, T. J., E. A. Foegeding, and M. A. Drake. 2015b. Sensory and functionality differences of whey protein isolate bleached by hydrogen or benzyl peroxide. J. Food Sci. 80:C2153-C2160.

Smith, T. J., E. A. Foegeding, and M. A. Drake. 2016a. Flavor and functional characteristics of whey protein isolates from different whey sources. J. Food Sci. 81:C849-C857.

Smith, T. J., P. D. Gerard, and M. A. Drake. 2015a. Effect of temperature and concentration on benzoyl peroxide bleaching efficacy and benzoic acid levels in whey protein concentrate. J. Dairy Sci. 98:7614-7627.

Smith, T. J., X. E. Li, and M. A. Drake. 2014. Norbixin and bixin partitioning in Cheddar cheese and whey. J. Dairy Sci. 97:3321-3327.

Smithers, G. W. 2015. Whey-ing up the options-Yesterday, today, and tomorrow. Int. Dairy J. 48:2-14.

Stevenson, R. J., X. D. Chen, and O. E. Mills. 1996. Modern analyses and binding studies of flavor volatiles with particular reference to dairy protein products. Food Res. Int. 29:265-290.

Stout, M. A., C. W. Park, and M. A. Drake. 2017. The effect of bleaching agent on the degradation of vitamins and carotenoids in spray dried whey protein concentrate. J. Dairy Sci. 100:7922-7932.

Swaisgood, H. E. 1996. Characteristics of milk. Pages 841-876 in Food Chemistry. 3rd ed. O. R. Fennema, ed. Marcel Dekker, New York, NY.

Szweda, R. T., K. Schmidt, and H. Zorn. 2013. Bleaching of colored whey and milk by a multiple-enzyme system. Eur. Food Res. Technol. 237:377-384.

Tomaino, R. M., L. G. Turner, and D. K. Larick. 2004. The effect of Lactococcus lactis starter cultures on the oxidative stability of liquid whey. J. Dairy Sci. 87:300-307.
Tunick, M. H. 2008. Whey protein production and utilization: A brief history. Pages 1-15 in Whey Processing, Functionality, and Health Benefits. Onwulata, C.I., Huth, P.J., ed. Wiley-Blackwell, Ames, IA.

Tunick, M. H., A. Thomas-Gahring, D. L. Van Hekken, S. K. Iandola, M. Singh, P. X. Qi, D. O. Ukuku, S. Mukhopadhyay, C. I. Onwulata, and P. M. Tomasula. 2016. Physical and chemical changes in whey protein concentrate stored at elevated temperature and humidity. J. Dairy Sci. 99:2372-2383.

U.S. Dairy Export Council. 2004. Reference Manual for US Whey and Lactose Products. Accessed Mar. 9, 2017. http://usdec.files .cms-plus.com/PDFs/2008ReferenceManuals/Whey_Lactose _Reference_Manual_Complete2_Optimized.pdf.

USDA. 2010. Dairy Products 2009 Summary: USDA. Accessed Mar. 3, 2017. http://usda.mannlib.cornell.edu/usda/nass/DairProdSu// 2010s/2010/DairProdSu-04-29-2010.pdf.

Van Ruth, S. M., and C. H. O'Connor. 2001. Evaluation of three gas chromatography-olfactmetry methods: comparison of odour intensity-concentration relationships of eight volatile compounds with sensory headspace data. Food Chem. 74:341-347.

White, S. S., K. M. Fox, S. M. Jervis, and M. A. Drake. 2013. Influence of heating and acidification on the flavor of whey protein isolate. J. Dairy Sci. 96:1366-1379.

Whitson, M. E., R. E. Miracle, E. Bastian, and M. A. Drake. 2011 Effect of liquid retentate storage on flavor of spray-dried whey protein concentrate and isolate. J. Dairy Sci. 94:3747-3760.

Whitson, M. E., R. E. Miracle, and M. A. Drake. 2010. Sensory characterization of chemical components responsible for cardboard flavor in whey protein. J. Sens. Stud. 25:616-636.

Wright, B. J., S. E. Zevchak, J. M. Wright, and M. A. Drake. 2009. Impact of agglomeration on flavor and flavor stability of whey proteins. J. Food Sci. 74:S17-S29.

Wright, J. W., M. E. Carunchia-Whetstine, R. E. Miracle, and M. A. Drake. 2006. Characterization of cabbage off-flavor in whey protein isolate. J. Food Sci. 71:C86-C90.

Zhang, Y., R. E. Campbell, M. A. Drake, and Q. Zhong. 2015. Decolorization of Cheddar cheese whey by activated carbon. J. Dairy Sci. 98:2982-2991.

Zhu, D., and S. Damodaran. 2012. Short communication: Annatto in Cheddar cheese-derived whey protein concentrate is primarily associated with milk fat globule membrane. J. Dairy Sci. 95:614-617.

Zorn, H., M. Scheibner, B. Hülsdau, R. G. Berger, L. De Boer, and R. B. Meima. 2010 Novel enzymes for use in enzymatic bleaching of food products. Nixon \& Vanderhye PC, assignee. US Pat. No. $20100055237 \mathrm{~A} 1$.

Zulewska, J., M. Newbold, and D. M. Barbano. 2009. Efficiency of serum protein removal from skim milk with ceramic and polymeric membranes at $50^{\circ}$ C. J. Dairy Sci. 92:1361-1377. 